\title{
Pengaruh Pembiayaan Mudharabah dan Musyarakah Terhadap ROE Pada Bank BCA Syariah
}

\section{The Effect Of Mudharabah and Musyarakah Financing On ROE At Bank BCA Syariah}

\author{
Alifia Rizqi Nurul Aziza ${ }^{1 *}$, Nana Diana ${ }^{2}$ \\ ${ }^{12}$ Prodi Akuntansi, Fakultas Ekonomi dan Bisnis, Universitas Singaperbangsa Karawang \\ Jl. HS. Ronggo Waluyo, Telukjambe Timur, Karawang, Jawa Barat, 41361, Indonesia \\ *E-mail: alifianurul78@gmail.com
}

\begin{abstract}
ABSTRAK
Tingginya tingkat ROE menggambarkan bahwa laba pada perusahaan tinggi sehingga kinerja manajemen dalam mengelola perusahaan dianggap baik. Penelitian memiliki tujuan untuk menganalisis Return On Equity (ROE) dipengaruhi atau tidak oleh pembiayaan mudharabah dan pembiayaan musyarakah pada Bank BCA Syariah. Data diambil dari laporan keuangan pada Bank BCA Syariah periode 2017-2019. Penelitian deskriptif dengan menggunakan pendekatan kuantitatif mencakup jenis penelitian ini. Teknik analisis yang dipergunakan terdiri dari analisis regresi berganda, analisis statistik deskriptif, uji asumsi klasik, dan uji hipotesis. Hasil dari pengujian menyatakan bahwa pembiayaan mudharabah tidak berpengaruh tetapi berarah negatif terhadap ROE secara parsial. Pembiayaan musyarakah berpengaruh positif signifikan terhadap Return On Equity secara parsial.
\end{abstract}

Kata kunci: mudharabah, musyarakah, ROE.

\section{ABSTRACT}

The high level of ROE illustrates that the company's income is high so that management performance in managing the company is considered good. This research aims to analyze the Return On Equity (ROE) influenced or not by mudharabah financing and musyarakah financing at Bank BCA Syariah. Data is taken from financial reports at Bank BCA Syariah for the 2017-2019 period. Descriptive research using a quantitative approach includes this type of research. The analysis technique used consists of multiple regression analysis, descriptive statistical analysis, classical assumption test, and hypothesis testing. The results of the test state that mudharabah financing has no effect but is partially negative towards ROE. Musyarakah financing has a significant positive effect on Return On Equity partially.

Keywords: mudharabah, musyarakah, ROE.

Copyright @ 2021 Program Studi Ekonomi Perbankan Islam, FAI Universitas Majalengka. All rights reserved. 


\section{PENDAHULUAN}

Perbankan menjadi salah satu dasar kemajuan suatu negara saat mengatur perekonomian didasari dari berbagai penerbitan kebijakan. Pertumbuhan ekonomi negara bergantung pada peran perbankan dalam mengatasi perekonomian negara. Bank merupakan lembaga usaha untuk menghimpun dan menyalurkan dana yang dimiliki masyarakat baik dalam bentuk pinjaman maupun lainnya yang berguna untuk meningkatkan kesejahteraan hidup masyarakat. Berdasarkan prinsipnya, perbankan mencakup bank syariah dan bank konvensional. Bank konvesional menerapkan prinsip bunga dan pada bank syariah menerapkan bagi hasil dari situlah terlihat perbedaan prinsipnya.

Indonesia memiliki penduduk dengan mayoritas menganut agama Islam. Hal ini membuat perbankan syariah terus berkembang dan eksistensi pada kalangan masyarakat seiring dengan meningkatnya permintaan dan berkembangnya pemikiran pada masyarakat. Bank syariah merupakan lembaga perantara dalam menyalurkan serta menampung dana masyarakat dengan tujuan meningkatkan kesejahteraan yang berpedoman pada syariat Islam. Lalu dana akan disimpan dalam bentuk deposito, tabungan maupun giro menggunakan prinsip mudharabah dan wadiah. Pada Bank Syariah, dana disalurkan menurut jenis akad yang digunakan yaitu pembiayaan bagi hasil berupa musyarakah dan mudharabah. Pembiayaan mudharabah yaitu pembiayaan menggunakan akad antara pengelola usaha dan pemilik modal yang memiliki tujuan untuk memperoleh laba dimana laba akan dibagi setara dengan kontrak yang sudah disepakati dengan risiko pemilik modal yang menanggung. Pembiayaan musyarakah yakni pembiayaan menggunakan akad yang dilakukan pengelola usaha dengan pemilik modal untuk saling berkontribusi memberikan dana pada suatu usaha dengan kesepakatan yang telah disepakati bahwa laba yang didapat dan risiko usaha yang mungkin terjadi akan ditanggung kedua belah pihak.
Indikasi dari semakin berkembangnya lembaga berbasis syariah didasari pada beberapa hal yaitu terjadi peningkatan dari total lembaga keuangan syariah dibuktikan dari jumlah aset yang sebesar USD 94,44 miliar dengan rasio dari pangsa pasar 8,29\%, penerbitan Sovereign Green Sukuk diterbitkan oleh Indonesia tahun 2019 membuat Indonesia bisa mengumpulkan dana mencapai USD 2 miliar, dan memperoleh penghargaan posisi pertama pada Islamic Finance Country Index (IFCI) 2019 dengan total poin 81,93 (OJK,2020). Berdasarkan data Global Islamic Economy indicator (GIEI), saat kategori Top Ten Islamic Finance, tahun 2019 terjadi kenaikan peringkat yaitu berada pada peringkat 5 . Tahun 2015 sampai dengan 2016, Indonesia masuk diurutan ke-9 dan tahun 2017 hingga 2018 Indonesia berada pada peringkat 10.

Menurut data pada tahun 2019 total Bank Syariah di Indonesia mencapai 189 salah satunya yaitu PT. Bank BCA Syariah. Pesatnya perkembangan dunia perbankan syariah membuat bertambahnya daya tarik masyarakat terhadap ekonomi syariah sehingga PT Bank Central Asia, Tbk melakukan tindakan berupa akuisisi pada PT Bank Utama Internasional Bank guna mencukupi keperluan masyarakat mengenai layanan syariah. No. 12/13/KEP.GBI/DpG/2010 atas keputusan Gubernur BI pada 2 Maret 2009, PT. Bank BCA Syariah menerima izin operasi syariah untuk memulai aktifitas usaha berpedoman pada prinsip-prinsip syariah dan tanggal 5 April 2010 resmi berjalan menjadi bank syariah.

Suatu lembaga usaha seperti bank syariah perlu menujukkan kinerja yang baik untuk meningkatkan kepercayaan masyarakat agar mau terus melakukan transaksi pada bank syariah salah satunya dengan meningkatkan profitabilitas. Kinerja suatu perusahaan diukur menggunakan rasio profitabilitas, salah satunya yaitu Return On Equity (ROE). Kegunaan dari ROE yaitu memperlihatkan cara kerja manajemen saat dikelolanya modal usaha pada bank dengan tujuan menghasilkan laba. Investor akan memantau 
nilai Return On Equity (ROE) perusahaan membandingkan daya kerja usaha menyangkut pengembalian modal saat laba diperoleh. Jika pembiayaan tidak memperoleh hasil sesuai target, maka bank akan mengalami kendala dalam memperoleh tambahan modal. Tingkat tinggi rendahnya Return On Equity (ROE) pada bank didapatkan dari hasil perbandingan dari laba setelah pajak dan ekuitas yang ada. Tingginya tingkat ROE menggambarkan bahwa laba bersih pada perusahaan tinggi sehingga kinerja manajemen dalam mengelola perusahaan dianggap baik. Secara teori, aktivitas pembiayaan yang disalurkan bank semakin besar kepada nasabah maka profit yang diperoleh bank akan tinggi juga, sehingga hal tersebut dapat membantu bank dalam pengembalian modal atau dengan kata lain nilai akan tinggi pada ROE.

Bank BCA Syariah berhasil mencatat kinerja positif tahun 2019 dengan perolehan laba bersih $\mathrm{Rp} 67,5$ miliar naik 15,1\% dibandingkan tahun 2018 (year on year/yoy). Terjadinya peningkatan laba tersebut dilandasi dari adanya kenaikan aset yang dimiliki Bank BCA Syariah sebesar Rp 8,6 triliun atau tumbuh $22,3 \%$. Total ekuitas pada tahun 2019 mengalami peningkatan Rp 2,3 triliun dari semula Rp 1,2 triliun tahun 2018. Tersalur pembiayaan Bank BCA syariah saat Desember 2019 Rp 5,6 triliun naik 15,2\%. Bank BCA Syariah tahun 2019 memiliki penurunan nilai ROE sebesar $4,0 \%$.

Pengaruh pembiayaan mudharabah dan musyarakah terhadap ROE sebelumnya telah diteliti penelitian lain seperti penelitian Rahayu et al., (2016) mendapatkan hasil bahwa pembiayaan mudharabah secara parsial mempengaruhi ROE secara positif, hal ini terjadi karena adanya kenaikan pembiayaaan. Sementara itu, pengaruh pembiayaan musyarakah terhadap Return On Equity (ROE) secara parsial memberikan pengaruh negatif. Penelitian Arifianto \& Apollo (2020) menunjukkan hasil pembiayaan mudharabah berpengaruh terhadap Return On Equity dan musyarakah tidak berpengaruh terhadap Return On Equity. Penelitian Auditya \& Afridani (2019) menunjukkan hasil bahwa pembiayaan musyarakah tidak berpengaruh signifikan terhadap Return On Equity sehingga besar tidaknya pembiayaan yang tersalur oleh bank tidak ada pengaruh terhadap ROE. Penelitian Mahmudin (2018) menujukkan hasil bahwa memiliki pengaruh signifikan antara pembiayaan mudharabah dengan ROE. Penelitian Widianengsih et al. (2020) menyatakan pembiayaan mudharabah secara tidak berpengaruh secara parsial terhadap profitabilitas dan pembiayaan musyarakah secara parsial berpengaruh positif signifikan terhadap profitabilitas.

Berdasarakan pemaparan diatas, penulis tertarik untuk meneliti terkait pengaruh dari pembiayaan mudharabah dan musyarakah terhadap ROE. Peneliti menggunakan data dari PT BCA Syarah tahun 2017-2019. Dilakukannya penelitian dengan tujuan menguji pengaruh dari pembiayaan mudharabah dan musyarakah terhadap ROE. Diharapkan hasil peneitian dapat menjadi referensi manajemen bank dalam menjalakan kegiatannya dengan baik dan menjadi evaluasi dari bank dalam pengambilan keputusan. Penulis akan meneliti terkait hal tersebut menggunakan judul "Pengaruh Pembiayaan Mudharabah Dan Musyarakah Terhadap ROE Pada Bank BCA Syariah".

\section{METODE}

Pendekatan kuantitatif menggunakan penelitian deskriptif merupakan jenis penelitian yang diterapkan. Metode analisis yang dipergunakan terdiri dari analisis regresi berganda, uji hipotesis, uji asumsi klasik, dan statistik deskriptif.

\section{Populasi dan Sampel}

Populasi berasal dari laporan keuangan bulanan Bank BCA Syariah Tahun 2017-2019. Sumber data penelitian data sekunder diambil dari web Bank BCA Syariah. Uji sampel data 36 diambil perbulan selama 3 tahun dari laporan kuangan Bank syariah.

\section{Variabel Independen \\ Pembiayaan Mudharabah}

Pembiayaan menggunakan akad yang dilakukan pengelola dengan pemilik modal 
yang memiliki tujuan untuk memperoleh laba dimana laba akan dibagi setara dengan kontrak yang sudah disepakati dengan risiko akan ditanggung oleh pemilik modal yakni pengertian dari pembiyaan mudharabah. (Hasibuan, 2020). Unsur dari mudharabah yaitu ditentukannya pihak pemilik dana dan pihak pengelola dana. Perhitungan pembagian hasil pada mudharabah sesuai kontrak dibagi oleh mudharib, karena pada pembiayaan mudharabah pemilik modal hanya mendapatkan wewenang untuk menjalankan usaha dan tidak diperkenankan terlibat dalam manajemen usaha. (Wiroso, 2011).

\section{Pembiayaan Musyarakah}

Pembiayaan musyarakah yaitu pembiayaan menggunakan akad pengelola dengan pemilik modal yang saling berkontribusi memberikan dana pada suatu usaha dengan kesepakatan yang telah disepakati bahwa laba yang didapat dan risiko usaha yang mungkin terjadi akan ditanggung kedua belah pihak. Rukun dari musyarakah yaitu adanya ijab qabul pihak-pihak yang berkontribusi dengan perincian dari persetujuan. Laba musyarakah dibagikan sesuai dengan kontrak yang disepakati atau sesuai dengan modal yang diberikan. Jika mengalami defisit maka akan dibebankan sesuai dengan modal yang diberikan. (Wiroso, 2011).

\section{Variabel Dependen \\ Return On Equity (ROE)}

Rasio yang berfungsi menguji cara kerja usaha saat dikelolanya modal pada perusahaan dengan tujuan diperolehnya laba disebut Return On Equity. Rasio tersebut menunjukkan efisiensi manajemen bank dalam penggunaan modal suatu perusahaan. (Kusuma, 2019). Nilai Return On Equity (ROE) yang tinggi menandakan semakin bagus kinerja perusahaan sehingga posisi dari pemilik perusahaan semakin kuat, begitupun sebaliknya. Pada Return On Equity (ROE) laba yang diperhitungkan yaitu Earning After Interest and Tax. (Kasmir, 2017). Berikut ini rumus dari ROE yaitu :

\section{$\mathrm{ROE}=$ Earning After Interest and Tax Equity}

\section{Hipotesis}

Hipotesis yakni perolehan dari pengujian suatu penelitian bersifat sementara terhadap suatu permasalah yang sedang dilakukan penelitian sampai terbukti melalui data yang telah dikumpulkan.

$\mathrm{H}_{1}$ : Adanya pengaruh secara parsial dalam pembiayaan mudharabah terhadap Return On Equity (ROE) pada Bank BCA Syariah.

$\mathrm{H}_{2}$ : Adanya pengaruh secara parsial dalam pembiayaan musyarakah terhadap Return On Equity (ROE) pada Bank BCA Syariah.

$\mathrm{H}_{3}$ : Adanya pengaruh secara simultan dalam pembiayaan mudharabah dan musyarakah terhadap Return On Equity (ROE) pada Bank BCA Syariah.

\section{HASIL DAN PEMBAHASAN \\ Statistik Deskriptif}

Analisis berguna untuk memperlihatkan karakteristik dari data yang diuji seperti quartile, verian, mean serta standart deviation. Tahap dari analisis ini, erat kaitannya dengan pengumpulan, peringkasan, dan penyajian dari ringkasan. Nilai dari hasil pengelohan uji $X_{1}, X_{2}$ dan $Y$ yaitu :

Tabel 1

Hasil Statistik Deskriptif

\begin{tabular}{|c|c|c|c|c|c|}
\hline & $\mathrm{N}$ & Min & Max & Mean & Std. Dev \\
\hline Mudharabah & 36 & $\begin{array}{l}16599 \\
9\end{array}$ & $\begin{array}{l}49069 \\
1\end{array}$ & $\begin{array}{l}287323,9 \\
7\end{array}$ & $\begin{array}{l}79877,15 \\
5\end{array}$ \\
\hline Musyarakah & 36 & $\begin{array}{l}12778 \\
82\end{array}$ & $\begin{array}{l}30097 \\
65\end{array}$ & $\begin{array}{l}2031524 \\
14\end{array}$ & $\begin{array}{l}436267,3 \\
61\end{array}$ \\
\hline ROE & 36 & & & & \\
\hline Valid N & 36 & & & & \\
\hline
\end{tabular}

Sumber: hasil spss 16, 2021

Berdasarkan tabel hasil dari analisis deskriptif diatas, bahwa dilihat dari nilai $\mathrm{N}$ maka data yang terpakai sebanyak 36. Data digunakan dari laporan keuangan Bank BCA Syariah tahun 2017-2019. Pada hasil 
pengolahan data pembiayaan mudharabah, mean sebesar 287327,97 nilainya lebih tinggi dari standard deviation sebesar 79877,155. Nilai minimum pada pembiayaan mudharabah yaitu 165999 dan nilai maximum sebesar 490691. Pada hasil pengolahan data pembiayaan musyarakah, mean sebesar 2031524,14 sedangkan nilai standart deviation sebesar 436267,361. Nilai minimum dari pembiayaan musyarakah sebesar 1277882 dan nilai maksimum sebesar 3009765. Pada hasil pengolahan data Return On Equity (ROE), mean sebesar 1,9950 dan standart deviation sebesar 1,12786. Nilai minimum 0,27 dan 4,30 nilai maximum. Dari penjelasan diatas, penelitian ini memiliki distribusi normal hal tersebut karena nilai mean lebih besar dari nilai standart

\begin{tabular}{|ll|l|l|}
\hline & & \multicolumn{2}{|l|}{} \\
& & \multicolumn{2}{|l|}{ Collinearity Statistics } \\
\cline { 2 - 4 } & Model & Tolerance & VIF \\
\hline 1 & Mudharabah & 0,545 & 1,835 \\
& Musyarakah & 0,545 & 1,835 \\
\hline
\end{tabular}

deviniation.

\section{Uji Asumsi Klasik \\ Uji Normalitas}

Dalam penelitian, pengujian berfungsi dalam membaca penyebaran data pada variabel bebas serta terikat yang diujikan dimana data yang bagus merupakan data dengan distribusi normal.

Tabel 2.

Uji Non Parametrik Kolmogorov-Smirnov

\begin{tabular}{|c|c|c|}
\hline & & $\begin{array}{l}\text { Unstandardiz } \\
\text { ed Residual }\end{array}$ \\
\hline N & & 36 \\
\hline \multirow[t]{2}{*}{ Normal Parameters ${ }^{a}$} & Mean & 0,0000000 \\
\hline & Std. Dev & 1,04632304 \\
\hline \multirow{3}{*}{$\begin{array}{l}\text { Most } \\
\text { Differences }\end{array}$} & Absolute & 0,083 \\
\hline & Positive & 0,083 \\
\hline & Negative & $-0,078$ \\
\hline
\end{tabular}

\begin{tabular}{|l|l|} 
Kolmogorov-Smirnov Z & 0,500 \\
Asymp. Sig. (2-tailed) & 0,964 \\
\hline
\end{tabular}

Sumber: hasil spss 16, 2021

Hasi pengujian dapat diperhatikan ditabel 2, sampel terdiri dari 36 data. Nilai dari Asymp. Sig. yakni 0,964, nilai itu menjadi $0,964>0,05$. Maka ditarik kesimpulan data pada penelitian tersebar dengan normal.

\section{Uji Multikolinieritas}

Dalam sebuah penelitian, uji multikolinieritas digunakan dalam menguji variabel bebas yang kemungkinan mempunyai kesamaan diantara variabel bebas lainnya dalam penelitian. Jika terjadi persamaan antar variabel bebas maka akan menimbulkan korelasi yang kuat. Dalam mengetahui gejala multikolinearitas dapat terbaca dari VIF dan Tolerance. Dikatakan tidak mengalami gejala multikoliniearita jika Variance Inflation Factor (VIF) diantara 1-10 serta Tolerance lebih dari 0,1.

Tabel 3

Hasil Uji Multiikolinieritas

Sumber: hasil spss 16, 2021

Pengujian mengenai multikolinieritas dapat dilihat tabel 3. Pada coeffients, pembiayaan mudharabah dan pembiayaan musyarakah memperoleh nilai VIF lebih yaitu 1,835. Tolerance pada $X_{1}$ dan $X_{2}$ lebih dari 0,1 yakni 0,545 . Maka ditarik kesimpulan pada hasil uji ini tidak terdapat multikolinearitas.

\section{Uji Heteroskedastisitas}

Pada suatu penelitian, uji ini digunakan dalam mencari kemungkinan adanya perbedaan variabel residual suatu periode pengamatan. Pada pola gambar scatterplot, dapat diperhatikan kemungkinan muncul gejala heteroskedastisitas. Jika penyebaran pola pada gambar tidak terlihat pola tertentu dan titik berpencar maka tidak terjadi gejala heteroskedastisitas. Titik penyebar tersebar dilingkup angka 0. 


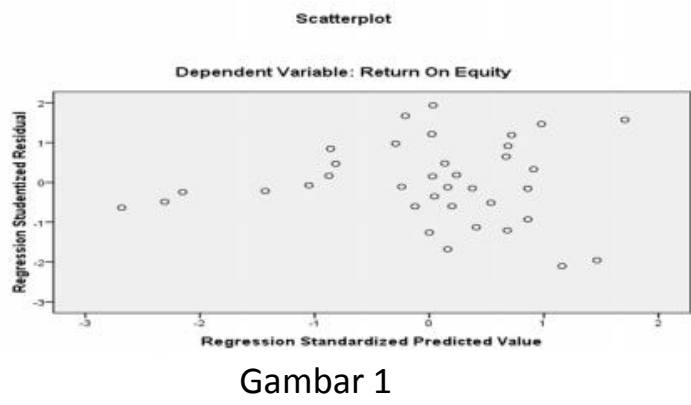

Hasil Uji Heteroskedastisitas

Sumber: hasil spss 16, 2021

Pengujian mengenai heteroskedastisitas dapat diperhatikan dalam gambar 2. Titik terlihat terpencar dan tidak terbentuk pola pada penyebarannya. Titik persebaran data tersebar secara baik. Maka ditarik kesimpulan tidak terdapat gejala heteroskedastisitas dan uji regesi layak untuk diuji dalam uji $Y$ berdasarkan masukan X1 dan X2.

\section{Uji Autokorelasi}

Dalam suatu penelitian, uji ini digunakan untuk memperlihatkan kemungkinan muncul hubungan variabel pengganggu dari variabel sebelumnya pada suatu periode. Cara terdeteksinya gejala autokorelasi yakni perbandingan tabel Durbin Watson dan nilai Durbin Watson ( $d u$ dan $d l)$. Spesifikasi dalam uji ini yaitu jika nilai $D-W<-2$ maka terdapat gelaja autokorelasi positif. Jika $-2<\mathrm{D}-\mathrm{W}>2$ maka tidak terjadi gejala autokorelasi. Jika nilai dari D-W > 2 maka gejala autokorelasi negatif.

Tabel 4.

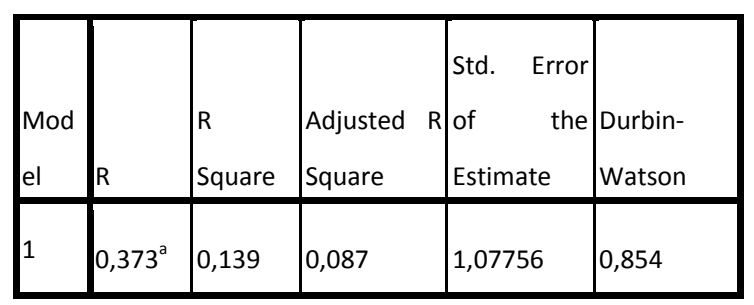

Uji Autokorelasi

Sumber: hasil spss 16, 2021

Pada tabel 5 , nilai dari D-W yakni 0,854 sehingga tidak ada gejala autokorelasi karena nilainya masih di antara -2 dan +2 .

\section{Analisis Regresi Linier Berganda}

Pada suatu penelitian, analisis ini berfungsi mempelihatkan pengaruh dan nilai dari $X_{1}$ dan $X_{2}$ terhadap $Y$. Model dari analisis regresi linier berganda yaitu $Y=a+b_{1} X_{1}+b_{2}$ $\mathrm{X}_{2}$

Tabel 5

Uji Regresi Linier Berganda

\begin{tabular}{|c|c|c|c|c|c|c|}
\hline \multirow{2}{*}{\multicolumn{2}{|c|}{ Model }} & \multicolumn{2}{|c|}{$\begin{array}{l}\text { Unstand. } \\
\text { Coefficients }\end{array}$} & \multirow{2}{*}{\begin{tabular}{|l}
$\begin{array}{l}\text { Stand. } \\
\text { Coefficie } \\
\text { nts }\end{array}$ \\
Beta
\end{tabular}} & \multirow[b]{2}{*}{$\mathrm{t}$} & \multirow[b]{2}{*}{ Sig. } \\
\hline & & B & $\begin{array}{l}\text { Std. } \\
\text { Error }\end{array}$ & & & \\
\hline \multirow[t]{4}{*}{1} & (Constant) & 0,607 & 0,874 & & 0,694 & 0,492 \\
\hline & Mudharabah & & & & & \\
\hline & & $\begin{array}{l}4,384 \mathrm{E}- \\
6\end{array}$ & 0,000 & $-0,310$ & 1,419 & 0,165 \\
\hline & Musyarakah & $\begin{array}{l}1,303 \mathrm{E}- \\
6\end{array}$ & 0,000 & 0,504 & 2,304 & 0,028 \\
\hline
\end{tabular}

Sumber: hasil spss 16, 2021

Dari pengolahan pada tabel 6, persamaan dari analasis regresi linier berganda yaitu ROE $=0,607+-4,38 X_{1}+1,202 X_{2}$.

\section{Uji Hipotesis}

\section{Uji T (Parsial)}

Pada suatu penelitian, uji $t$ (parsial) berfungsi untuk analisis atas pengaruh variabel bebas terhadap variabel terikat secara parsial. Dasar dari penentuan keputusan terhadap uji parsial menggunakan nilai sig. dan membandingkan $t_{\text {hitung }}$ dengan $t$ tabel. Jika $t_{\text {hitung }}>t_{\text {tabel }}$ atau $\alpha=0,05>$ sig, Ho akan ditolak. Hal ini berarti variabel bebas memiliki pengaruh signifikan terhadap variabel terikat.

Tabel 6

Hasil Uji t

\begin{tabular}{|c|c|c|c|c|c|c|}
\hline \multirow{2}{*}{\multicolumn{2}{|c|}{ Model }} & \multicolumn{2}{|c|}{$\begin{array}{l}\text { Unstand. } \\
\text { Coefficients }\end{array}$} & \multirow{2}{*}{$\begin{array}{l}\text { Stand. } \\
\text { Coefficie } \\
\text { nts }\end{array}$} & \multirow[b]{2}{*}{$\mathrm{t}$} & \multirow[b]{2}{*}{ Sig. } \\
\hline & & $B$ & $\begin{array}{l}\text { Std. } \\
\text { Error }\end{array}$ & & & \\
\hline \multirow[t]{4}{*}{1} & (Constant) & 0,607 & 0,874 & & 0,694 & 0,492 \\
\hline & Mudharabah & & & & & \\
\hline & & $\begin{array}{l}4,384 \mathrm{E}- \\
6\end{array}$ & 0,000 & $-0,310$ & 1,419 & 0,165 \\
\hline & Musyarakah & $\mid \begin{array}{l}1,303 \mathrm{E}- \\
6\end{array}$ & 0,000 & 0,504 & 2,304 & 0,028 \\
\hline
\end{tabular}

Sumber: hasil spss 16, 2021

Hasil dari uji t-statistik (parsial) dapat dilihat pada tabel di atas. 
1. Pengaruh variabel $X_{1}$ terhadap $Y$

Hipotesis 1 menyebutkan pembiayaan mudharabah memiliki pengaruh terhadap Return On Equity (ROE). Pengujian dari hipotesis 1 didapatkan hasil $t$ hitung yakni -1,419 dengan $t$ tabel yakni 2,035 serta signifikansi $0,165>0,05$. Maka dari itu, H1 ditolak karena pada hasil pengujian hipotesis 1 tidak berpengaruh tetapi berarah negatif.

2. Pengaruh variabel $X_{2}$ terhadap $Y$

Hipotesis 2 menyebutkan ada pengaruh pembiayaan musyarakah terhadap ROE. Pengujian hipotesis 2 didapatkan hasil bahwa $\mathrm{t}_{\text {hitung }} 2,304$ dan $\mathrm{t}$ tabel 2,035 serta sig 0,028<0,05. Ditarik kesimpulan, $\mathrm{H} 2$ diterima karena pada hasil pengujian hipotesis mengenai pembiayaan musyarakah terhadap ROE berpengaruh dan signifikan.

\section{Uji F (Simultan)}

Pada suatu penelitian, uji $F$ (simultan) memiliki tujuan yaitu melihat variabel $X$ ada pengaruh atau tidaknya secara simultan terhadap Y.

Tabel 8.

\section{Hasil Uji F-statistik (Simultan)}

Sumber: hasil spss 16, 2021

Pengujian mengenai Uji simultan dapat dilihat pada tabel 7. $F_{\text {hitung }} 2,672$ dan nilai $F_{\text {tabel }}$ pada signifikansi 0,084 . Nilai dari derajat kebebasan sebesar $\mathrm{df} 1=2$ dan $\mathrm{df} 2=33$ sehingga diperoleh $F$ tabel $(2 ; 33)=3,285$. Perbandingan $\mathrm{F}_{\text {hitung }}$ dan $\mathrm{F}_{\text {tabel }}$ menjadi $2,672<$ 3,285 dimana $F_{\text {hitung }}<F_{\text {tabel }}$ maka Ha ditolak Ho diterima. Nilai signifikansi pada hasil pengolahan data 0,084 $>0,05$ sehingga $\mathrm{Ha}$ ditolak dan Ho diterima. Hal ini memiliki arti pengolahan data ROE secara simultan tidak mempengaruhi pembiayaan mudharabah dan musyarakah pada Bank BCA Syariah.

\section{Koefisien Determinasi $\left(\mathbf{R}^{2}\right)$}

Pengelolahaan data menggunakan uji ini memiliki tujuan untuk menilai kemampuan model menjabarkan variasi dari variabel terikat $(\mathrm{Y})$.
Tabel 9.

Uji Koefisien Determinasi

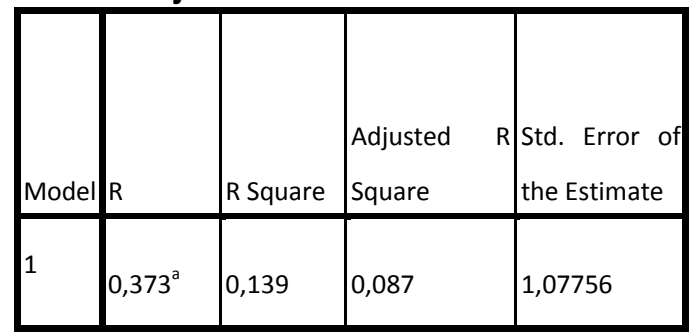

Sumber: hasil spss 16, 2021

Hasil pengolahan pada tabel 9, pembiayaan mudharabah dan musyarakah mempengaruhi peningkatan terhadap ROE. Hasil uji terlihat dari $\mathrm{R}$ Square 0,139 memperlihatkan Return On Equity (ROE) dipengaruhi $13,9 \%$ oleh pada pembiayaan mudharabah dan pembiayaan musyarakah, sebesar $86,1 \%$ disebabkan oleh hal lain.

\section{PEMBAHASAN}

\section{Pengaruh Pembiayaan Mudharabah Terhadap ROE}

Analisis dari hasil uji memperlihatkan jika terjadi kenaikan maupun penurunan nilai dari pembiayaan mudharabah tidak akan mempengaruhi nilai dari ROE secara parsial pada Bank BCA Syariah. Pembiayaan

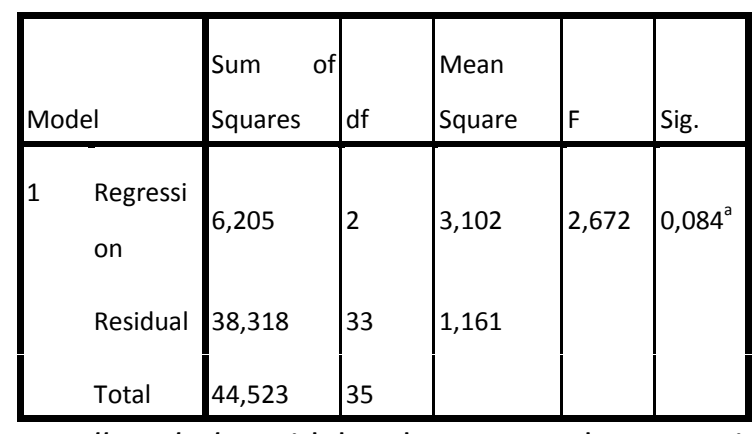

mudharabah tidak berpengaruh tetapi berarah negatif pada Return On Equity (ROE) karena nilai dari pembiayaan mudharabah yang disalurkan oleh Bank BCA syariah mengalami fluktuasi. Pada tahun 2017 nilai penyaluran dari pembiayaan mudharabah sebesar Rp 225,6 milyar sedangkan pada tahun 2016 sebesar Rp 345,8 milyar maka terjadi penurunan nilai sebesar $-34,8 \%$ pada penyaluran pembiayaan mudharabah.

Nisbah bersifat tidak pasti dan resiko yang relatif tinggi menyebabkan minat bank untuk menyalurkan dana pada pembiayaan 
mudharabah cenderung kurang. (Putra, 2018). Nilai besar kecilnya penyertaan modal pihak bank dalam pembiayaan mudharabah $100 \%$, sehingga menjadi penentu besar kecilnya perolehan laba. Serta resiko yang akan didapat pihak bank juga besar jika terjadi kerugian pada usaha yang dijalankan. (Permata \& Yaningwati, 2014).

Hasil dari penelitian serupa dengan penelitian Putra (2018) menyatakan mudharabah tidak berpengaruh terhadap tingkat profitabilitas. Pada penelitian Widianengsih et al., (2020) juga menyatakan mudharabah tidak berpengaruh terhadap ROE. Pada Penelitian Kusuma (2019) menyatakan pembiayaan mudharabah tidak memiliki pengaruh terhadap profitabilitas (ROE) Bank Muamalat Indonesia karena adanya impilikasi yang memungkinkan sikap oportunisik dikalangan manajemen perusahaan.

\section{Pengaruh Pembiayaan Musyarakah Terhadap ROE}

Analisis hasil uji memperlihatkan pembiayaan musyarakah mempunyai pengaruh secara signifikan terhadap ROE pada Bank BCA Syariah. Hasil ini membuktikan jika setiap kenaikan nilai pembiayaan musyarakah akan berpengaruh dengan nilai ROE dan jika nilai pembiayaan terjadi penurunan nilai pembiayaan musyarakah maka akan berpengaruh pada ROE. Nilai tinggi dari pembiayaan musyarakah yang tersalurkan diharapkan dapat memberikan peningkatan profitabilitas karena pembiayaan tersebut memiliki resiko lebih kecil dibandingkan pembiayaan lain. (Hasibuan, 2020).

Penerapan prinsip pembiayaan musyarakah berupa bagi hasil yang dalam proses usaha membutuhkan peran dari kedua pihak. Kedua pihak juga memiliki peran dalam penyertaan modal. Laba dan rugi yang terjadi akan dibagi oleh kedua pihak sesuai penyertaan modal usaha. Laba yang dihasilkan digunakan untuk pengembalian modal yang nantinya akan dialokasikan pada pembiayaan sehingga berpengaruh pada nilai dari ROE. (Permata \& Yaningwati, 2014).
Tahun 2017 nilai dari pembiayaan musyarakah sebesar Rp 1.834 milyar sedangkan pada tahun 2018 sebesar Rp $2.432,3$ milyar maka terjadi kenaikan $41,0 \%$. Pada tahun 2019 juga mengalami kenaikan pada pembiayaan musyarakah sebesar $23,7 \%$. Terjadinya peningkatan pada pembiayaan musyarakah menjadikan solusi untuk lebih mengoptimalkan penyaluran pembiayaan yang sesuai keperluan dari nasabah pada Bank BCA Syariah.

Hasil dari penelitian serupa pada penelitian Widianengsih et al. (2020) yang menyebutkan secara parsial ada pengaruh positif signifikan terhadap profitabilitas. Penelitian Rianti dan Elmanizar (2019) menyatakan pembiayaan musyarakah ada pengaruh terhadap Return On Equity (ROE) Bank syariah. Penelitian Hasibuan (2020) menyebutkan pembiayaan musyarakah ada pengaruh signifikan terhadap Return On Equity (ROE).

\section{Pengaruh Pembiayaan Mudharabah dan Musyarakah Terhadap ROE}

Analisis hasil uji memiliki arti ROE secara simultan tidak mempengaruhi pembiayaan mudharabah dan musyarakah pada Bank BCA Syariah. Hal ini berarti jika ada kenaikan atas pembiayaan mudharabah dan musyarakah yang dilakukan Bank BCA Syariah tidak akan berdampak pada ROE. Pembiayaan mudharabah dan musyarakah yaitu pembiayaan yang memakai akad kerja sama antara bank dan nasabah yang dilandasi dengan prinsip pembagian laba dan rugi berdasarkan perjanjian. Pendapatan yang didapatkan bank atas pembiayaan belum bisa mengimbangi biaya yang dikeluarkan sehingga pendapatan tersebut belum bisa digunakan untuk memaksimalkan kinerja bank dalam mendapatkan laba. (Khoirunnisa, 2016).

Pengumpulan dan pengalokasian dana pada pembiayaan mudharabah dan musyarakah yang dilakukan Bank BCA Syariah dalam menghasilkan laba untuk pengembalian modal yang teralokasi pada pembiayaan bukanlah menjadi sumber utama. (Permata \& Yaningwati, 2014). 
Profitabilitas dipengaruhi dari beberapa faktor yaitu tingkat dari pengembalian pinjaman bank, modal yang dimiliki bank, dan efesiensi pada biaya operasi. (Tanuatmodjo \& Suhendar, 2014). Hasil uji ini serupa dengan penelitian Widyasari (2018) yang menyebutkan pembiayaan mudharabah dan musyarakah berpengaruh negatif dan tidak signifikan terhadap profitabilitas (ROE).

\section{KESIMPULAN}

Kesimpulaan yang dipaparkan yaitu pembiayaan mudharabah tidak berpengaruh tetapi berarah negatif terhadap ROE secara parsial. Maka dari itu, jika terjadi peningkatan atau penurunan nilai dari pembiayaan mudharabah tidak berpengaruh terhadap tinggi rendahnya nilai pada ROE. Pembiayaan musyarakah berpengaruh positif signifikan terhadap ROE secara parsial. Jika terjadi peningkatan nilai dari pembiayaan musyarakah maka akan terjadi juga peningkatan pada Return On Equity (ROE). Apabila nilai pada pembiayaan musyarakah turun maka ROE nilainya akan turun. Pembiayaan mudharabah dan musyarakah secara simultan tidak berpengaruh terhadap ROE.

\section{SARAN}

Berdasarkan hasil uji dan pembahasan, saran yang dapat disampaikan peneliti yakni bagi Bank BCA Syariah untuk meningkatkan kinerja perusahaan untuk memperoleh tujuan yang direncanakan. Bank BCA Syariah perlu mempertahankan dan meningkatkan kinerjanya dalam melakukan pelayanan kepada nasabah melalui produk jasa yang ditawarkan. Tingginya kontribusi pembiayaan musyarakah terhadap Return On Equity menjadikan solusi bank dalam meningkatkan kinerjanya. Tingkat Return On Equity yang tinggi menggambarkan bahwa kinerja bank sudah dijalankan secara maksimal. Bagi peneliti berikutnya disarankan menambahkan pengujian variabel agar dapat dilakukan perbandingan dengan penelitian yang telah dilakukan. Diharapkan penelitian selanjutnya memperbanyak pengujian sampel dengan periode yang lebih lama agar dapat mengembangkan hasil penelitian yang nantinya menjadikan informasi bagi masyarakat.

\section{DAFTAR PUSTAKA}

Arifianto, T., \& Apollo. (2020). Pengaruh Bagi Hasil Pembiayaan Mudharabah Pembiayaan Musyarakah Dan Pembiayaan Murabahah Terhadap Profitabilitas. Jurnal IImu Manajemen Terapan, 1(4), 385-391. https://doi.org/10.31933/jimt.v1i4.190

Auditya, L., \& Afridani, L. (2019). Pengaruh Pembiayaan Musyarakah Terhadap Profitabilitas Pada Bank Umum Syariah (Bus) Periode 2015-2017. Jurnal BAABU AL-ILMI: Ekonomi Dan Perbankan Syariah, 3(2). https://doi.org/10.29300/ba.v3i2.1541

Hasibuan, S. R. (2020). Pengaruh Pembiayaan Mudharabah Dan Musyarakah Terhadap Return On Equity Pada Bank Syariah Di Indonesia. Skripsi, 5(1), 55.

Kasmir. (2017). Analisis Laporan Keuangan (1st ed.). PT RajaGrafindo Persada.

Khoerulloh, A. K., \& Syafei, R. (2019). Pengaruh Pendapatan Bagi Hasil Mudharabah dan Pendapatan Margin Murabahah Terhadap Laba Usaha pada BMT Muda Surabaya. Maro, Jurnal Ekonomi Syariah Dan Bisnis, 3(1), 38-54.

Khoirunnisa, I. (2016). Pengaruh Pembiayaan Jual Beli, Pembiayaan Bagi Hasil, Financing Deposit Ratio (Fdr) Dan Non Performing Financial (Npf) Terhadap Profitabilitas Bank Umum Syariah Di Indonesia Periode 2010 - 2014. Jurnal Ilmiah Mahasiswa FEB Universitas Brawijaya, 4, 1-21. https://jimfeb.ub.ac.id/index.php/jimfe b/article/view/2779

Kusuma, R. A. (2019). Pengaruh Pembiayaan Mudharabah, Pembiayaan Musyarakah, Pembiayaan Sewa/ljarah, dan Pembiayaan Murabahah Terhadap Profitabilitas Bank Muamalat Indonesia (Periode 2012-2018). In Analisis Fiqih dan Keuangan.

Mahmudin. (2018). Pengaruh Pembiayaan Mudharabah Terhadap Tingkat Return 
On Equity(Roe)Pada Bank Syariah Yang Terdaftar Di Bank Indonesia. February, 42-48.

Permata, R. I. D., \& Yaningwati, F. (2014). Analisis Pengaruh Pembiayaan Mudharabah Dan Musyarakah Terhadap Tingkat Profitabilitas (Return On Equity). Jurnal Administrasi Bisnis S1 Universitas Brawijaya, 12(1), 83022.

Putra, P. (2018). Pengaruh Pembiayaan Mudharabah, Musyarakah, Murabahah, Dan ljarah Terhadap Profitabilitas 4 Bank Umum Syariah Periode 2013-2016. Jurnal Organisasi Dan Manajemen, 14(2), 140-150. https://doi.org/10.33830/jom.v14i2.159 .2018

Rahayu, Y., Husaini, A., \& Azizah, D. (2016). Pengaruh Pembiayaan Bagi Hasil Mudharabah Dan Musyarakah Terhadap Profitabilitas (Studi pada Bank Umum Syariah yang terdaftar pada Bursa Efek Indonesia periode 2011-2014). Jurnal Administrasi Bisnis S1 Universitas Brawijaya, 33(1), 61-68.

Rianti, F. A., \& Elmanizar. (2019). Pengaruh Piutang Murabahah, Pembiayaan Mudharabah Dan Pembiayaan Musyarakah Terhadap Profitabilitas Bank Syariah. Journal of Chemical Information and Modeling, 53(9), 16891699.

Sujarweni, V. W. (2016). Kupas Tuntas Penelitian Akuntansi Dengan SPSS. Pustaka Baru Press.

Tanuatmodjo, H., \& Suhendar, C. Y. (2014). Pengaruh Pembiayaan Bagi Hasil Terhadap Profitabilitas Bank Syariah. Antologi Pendidikan Akuntansi Dan Keuangan, 2(2), 1-6.

Widianengsih, N., Diana, N., \& Suartini, S. (2020). Pengaruh Pembiayaan Murabahah , Mudharabah dan Musyarakah Terhadap Tingkat Profitabilitas Bank Syariah di Indonesia. Jurnal AKUNSIKA Akuntansi Dan Keuangan, Universitas Singaperbangsa Karawang, 1(1).

Widyasari, T. (2018). Pengaruh Pembiayaan Mudharabah, Musyarakah, dan Ijarah
Terhadap Profitabilitas Bank Syariah Mandiri Periode 2012-2016. Jurnal Penelitian STIE Ekuitas Bandung.

Wiroso. (2011). Produk Perbankan Syariah. In LPFE Usakti.

Yusuf, S. S. H. W. M. (2009). Akuntansi Perbankan Syariah. LPFE Usakti. 